University of Nebraska - Lincoln

DigitalCommons@University of Nebraska - Lincoln

Management Department Faculty Publications

Management Department

2010

Impact of Positive Psychological Capital on Employee Well-Being Over Time

James B. Avey

Central Washington University, aveyj@cwu.edu

Fred Luthans

University of Nebraska - Lincoln, fluthans1@unl.edu

Ronda M. Smith

University of Nebraska - Lincoln

Noel F. Palmer

University of Nebraska - Lincoln

Follow this and additional works at: https://digitalcommons.unl.edu/managementfacpub

Part of the Management Sciences and Quantitative Methods Commons

Avey, James B.; Luthans, Fred; Smith, Ronda M.; and Palmer, Noel F., "Impact of Positive Psychological Capital on Employee Well-Being Over Time" (2010). Management Department Faculty Publications. 55. https://digitalcommons.unl.edu/managementfacpub/55

This Article is brought to you for free and open access by the Management Department at DigitalCommons@University of Nebraska - Lincoln. It has been accepted for inclusion in Management Department Faculty Publications by an authorized administrator of DigitalCommons@University of Nebraska - Lincoln. 
Published in Journal of Occupational Health Psychology 15:1 (2010), pp. 17-28; DOI: 10.1037/a0016998

Copyright (C) 2010 American Psychological Association. Used by permission. "This article may not exactly

replicate the final version published in the APA journal. It is not the copy of record."

Submitted November 14, 2008; revised May 12, 2009; accepted June 7, 2009.

\title{
Impact of Positive Psychological Capital on Employee Well-Being Over Time
}

\author{
James B. Avey \\ Department of Management, College of Business, Central Washington University \\ Fred Luthans, Ronda M. Smith, Noel F. Palmer \\ Department of Management, University of Nebraska-Lincoln \\ Corresponding author - James B. Avey, Department of Management, College of Business, \\ Central Washington University, 400 E. University Way, Ellensburg, WA 98926-7485; e-mail aveyj@cwu.edu
}

\begin{abstract}
The recently recognized core construct of psychological capital or PsyCap (consisting of the positive psychological resources of efficacy, hope, optimism, and resilience) has been demonstrated to be related to various employee attitudinal, behavioral, and performance outcomes. However, to date, the impact of this positive core construct over time and on important employee well-being outcomes has not been tested. This study meets this need by analyzing the relationship between a broad cross-section of employees' $(N=280)$ level of PsyCap and two measures of psychological well-being over time. The results indicated that employees' PsyCap was related to both measures of well-being and, importantly, that PsyCap explained additional variance in these well-being measures over time. The limitations, needed future research, and practical implications conclude the article.
\end{abstract}

Keywords: psychological capital, well-being, positive organizational behavior

In helping to define the boundaries of occupational health psychology (OHP), Quick (1999, p. 123) notes that "OHP applies psychology in organizational settings for the improvement of work life, the protection and safety of workers, and the promotion of healthy work. Healthy work exists where people feel good, achieve high performance, and have high levels of well-being." In addition, the public health notions of prevention have been incorporated in OHP. For example, prevention models have been adopted and applied through interventions to prevent factors that detract from employee well-being in the workplace (e.g., see Quick, Quick, Nelson, \& Hurrell, 1997). Given the importance of employee wellbeing at work as well as enhancing the capability to develop it, the purpose of this article is to introduce and empirically test an emerging construct, psychological capital (PsyCap), that we propose is related to and may help facilitate the occupational health objective of attaining high levels of employee psychological well-being (PWB).

\section{Background of the Study}

Within the behavioral sciences in general and occupational health psychology in particular, there has been a specific focus on the importance of well-being, both physical and mental health, in affecting success in many life domains, including the workplace. Indeed, Seligman, Steen, Park, and Peterson (2005, p. 410) challenged the field by asking, "Can psychologists take what they have learned about the science and practice of treating mental illness and use it to create a practice of making people lastingly happier?" We propose that one important way of answering this challenge is to identify constructs such as positive PsyCap (e.g., see Luthans \& Avolio, 2009; Luthans, Avolio, Avey, \& Norman, 2007; Luthans \& Youssef, 2004; Luthans, Youssef, \& Avolio, 2007) that may be amenable to intervention and related to PWB.

PWB has been found to be related to both work and personal life outcomes. For example, there is considerable research on the relationship between PWB and performance at work (Cropanzano \& Wright, 1999; Wright, Bonett, \& Sweeney, 1993; Wright \& Cropanzano, 2000; 
Wright \& Staw, 1999) and successful relationships (Diener \& Seligman, 2002). Also, superior mental (KoivumaaHonkanen et al., 2004) and physical (Roysamb, Tawls, Reichborn-Kjenneruc, Neale, \& Harris, 2003) health and longevity (Danner, Snowdon, \& Friesen, 2001) have been found to covary with happiness and positivity levels. In other words, although correlational, the inference from this research is that one's PWB leads to desired outcomes at work and in life.

A more recent focus has been on the other direction of causality - that is, to recognize and demonstrate the important role that positivity may play in well-being. For example, in a meta-analysis that examined not only correlational studies, but also those using longitudinal and experimental designs, the results clearly indicated that positive, happy people had better physical and mental health outcomes and behavior (Lyubomirsky, King, \& Diener, 2005) and in a recent update of the literature, Lyubomirsky (2008, p. 25) concluded that happier, more positive people are "more resilient in the face of hardship, have stronger immune systems, and are physically healthier. Happy people even live longer." In particular, studies have shown the link between positive moods (Ostir, Markides, Peek, \& Goodwin, 2001), happiness (Graham, Eggers, \& Sukhtankar, 2004), life satisfaction (Mroczek \& Spiro, 2005), and positive self-perceptions (Levy, Slade, Kunkel, \& Kasl, 2002) and physical and mental health outcomes. Applied to the workplace, Wright (2003, p. 441) asserted that in taking a positive approach to organizational behavior, "More than just considering employees as a means to the desired end of higher organizational productivity, to make a truly valuable contribution to the field the mission of positive organizational behavior (POB) must also include the pursuit of employee happiness, health, and betterment issues as viable goals or ends in themselves." Moreover, this previous research and perspective of the relationship between positivity (as the antecedent, independent variable) and well-being the dependent variable or desired outcome is beginning to extend beyond individual level boundaries to an understanding of the contextual effects of an organization's positive social interactions on employee health and well-being (Heaphy \& Dutton, 2008).

Even though positive organizational behavior and $\mathrm{OHP}$ recognize well-being as an important outcome, the role of time and the nature and theoretical mechanisms of the positive antecedents to well-being have been given little attention. The exceptions have included Wright (2005) who noted that PWB, while generally considered to be trait-like, has still been demonstrated to vary over time and some positive psychologists who have suggested that cognitions or one's beliefs are important for shaping mental health ( $\mathrm{O}^{\prime}$ Brien \& Major, 2005). We use both of these positions as our theoretical foundation for deriving the hypotheses for this study. Specifically, we suggest that understanding the process and mechanisms that link cognitively based positive constructs with wellbeing over time can be found in psychological resource theories and the emerging second-order, core construct of PsyCap.

In a review of resource theories in psychology, Hobfoll (2002, p. 307) defines resources as "those entities that either are centrally valued in their own right (e.g., selfesteem, close attachments, health, and inner peace) or act as a means to obtain centrally valued ends (e.g., money, social support, and credit)." Along with attributes and skills, Lyubomirsky et al. (2005) propose that such resources help people thrive and succeed at work, in relationships and, with health. Furthermore, experimental studies have shown that those induced into a positive state report higher self-perceptions such as efficacy (Baron, 1990; Schuettler \& Kiviniemi, 2006), have optimistic expectations (Brown, 1984), and set higher goals for themselves (Baron, 1990; Hom \& Arbuckle, 1988). Conceptualizing positive psychological capacities (e.g., efficacy and optimism) as resources from which one can draw seems an important theoretical explanation of the mechanism by which such positive capacities impact one's well-being.

Many psychological resources have been studied in their dispositional as opposed to state-like form (e.g., dispositional optimism, see Carver \& Scheier, 2001). Furthermore, it is evident that many psychological resources are related; suggesting that if an individual is high in one resource, they are often high in others - that is, resources seem to act in concert (Cozzarelli, 1993). Researchers in occupational health and health psychology have demonstrated that well-being is impacted by: hope (see Snyder, Lehman, Kluck, \& Monsson, 2006, for a review), resiliency (Britt, Adler, \& Bartone, 2001; Ferris, Sinclair, \& Kline, 2005; Keyes, 2007; Williams \& Cooper, 1998), selfefficacy (see Axtell et al., 2000; Bandura, 1997; and Meier, Semmer, Elfering, \& Jacobshagen, 2008), and optimism (Carver et al., 2005). Indeed, Seligman's learned optimism intervention is cited by OHP scholars as an exemplar of primary prevention for individuals (Quick, 1999). Thus, we propose that capacities such as these may be further explored as components of a higher order construct, such as PsyCap with positive effects on well-being.

If we are to study resources with the aim of influencing well-being, it only follows that the study of malleable, state-like resources-those open to development through intervention-are likely to provide the greatest opportunity for enhancing employees' well-being. 
We propose that the recently emerging core construct of PsyCap consisting of the positive psychological, statelike positive resources of efficacy, hope, optimism, and resilience (see Luthans et al., 2008 and Luthans, Avolio, et al., 2007, for the "state-like" nature of PsyCap and that it is open to development through intervention) best represent the measured impact of employees' positivity in relation to their well-being.

Using an approach similar to that of Wright and Hobfoll (2004), wherein individuals use cognitive evaluations of the availability of resources as indicators in their global assessment of wellness, we propose that the presence of employees' positive beliefs and agentic intentions (Bandura, 2008), such as represented by their PsyCap, serve as cognitive resources and a reservoir from which they can draw from to influence their wellbeing. We first provide the foundation for psychological resource theory and employee well-being followed by the emergence of the field of positive organizational behavior (POB) and the core construct of PsyCap to derive the study hypotheses.

\section{Conservation of Resources Theory and Employee Well-Being}

Hobfoll (2002) not only reviewed psychological resource theories, but also highlighted common or unifying themes. Many of these theories included (1) some means of cognitive appraisal of the situation, and (2) an associated orientation toward goal accomplishment and success. Of particular relevance for our study is Conservation of Resources Theory or COR (Hobfoll, 1989). COR suggests that people "seek to obtain, retain, and protect resources and that stress occurs when resources are threatened with loss or are lost or when individuals fail to gain resources after substantive resource investment" (Hobfoll, 2002, p. 312). COR theory stands out in that it recognizes and emphasizes means for positive adaptation under circumstances of loss. Relevant to the workplace, COR theory highlights the importance of motivation for decisions involving "how employees acquire, maintain and foster the necessary resources to both meet their current work demands and to help guard against further resource depletion" (Wright \& Hobfoll, 2004, p. 390). One's ability to acquire and maintain resources is both a means and an end-a means for achieving success and ends that include adaptation, coping, and wellbeing. Furthermore, secondary work-related resources such as high levels of cognitive and emotional attach- ment to one's occupation (Wright \& Hobfoll, 2004) are important for influencing people's primary resources such as their well-being (Westman, Hobfoll, Chen, Davidson, \& Laski, 2005; Wright \& Bonett, 2007). Thus, COR theory serves as the theoretical foundation in this study for both the antecedent of positive PsyCap and the outcome of well-being.

Building on the foundation of COR theory in the workplace, we further use Wright and Bonett's (2007) concept of PWB in defining the criterion variable in this study. They note that PWB is marked by the relative presence of positive affect, and the relative absence of negative affect (Myers \& Diener, 1995). Although they refer to PWB as being a global construct, one that is not directly or generally associated with any specific domain, or situation (e.g., as a work context is associated with job satisfaction, Wright \& Cropanzano, 2000), it is clearly linked with organizationally relevant variables (e.g., performance and job satisfaction). PWB is a primary resource that is preserved by secondary work-related resources but has a reciprocal effect on these same resources (Wright \& Bonett, 2007; Wright, Cropanzano, \& Bonett, 2007).

Finally, PWB is a subjective experience. In other words, people are psychologically well to the extent that they believe themselves to be (Wright \& Bonett, 2007). Given this understanding of psychological wellness as a primary resource with reciprocal effects on work-related outcomes, it is important to consider how work-related, secondary resources may extend beyond performance at work to affect one's wellness.

\section{Positive Organizational Behavior and PsyCap}

Besides theoretical understanding of resources and wellness, the meaning and theoretical foundation for positive organizational behavior in general and PsyCap in particular must also be provided for the study. As early as 1954, Maslow had argued that psychology tended to focus more on the "darker, meaner half" of its potential (Maslow, 1954). He proposed the field should be more balanced in areas such as growth, contentment, optimism, and actualization of human potential. Positive psychology calling for more balance and focus on the positive as an academic domain of scholarly activity, was introduced into the literature with a special issue of the American Psychologist edited by Seligman and Csikszentmihalyi (2000). This special issue contained articles on positive constructs such as hope, adaptive men- 
tal mechanisms, optimism, subjective well-being, individual development and happiness. Soon after, Luthans (2002a, 2002b) introduced the term positive organizational behavior or $\mathrm{POB}$ to bring this positive psychology to the workplace (also see Cameron, Dutton, \& Quinn, 2003, and Wright, 2003). Although recognizing that the field of organizational behavior had given more recognition to a positive approach than had psychology as a whole (see Luthans \& Avolio, 2009, for a review of the origins and justification for POB), Luthans (2002a, p. 59), defined POB as "the study and application of positively oriented human resource strengths and psychological capacities that can be measured, developed, and effectively managed for performance improvement in today's workplace."

This definition of POB emphasizes positive constructs that are state-like and thus open to development. The intent was to draw attention to positive constructs that may have not been considered as a resource, strength or capacity worth developing (Luthans \& Avolio, 2009). More specifically, the inclusion criteria for POB constructs were the following: "(1) must be based on theory, research and valid measurement; (2) must be "statelike" (as opposed to more fixed "trait-like") and thus be open to development; and (3) must have performance impact" (Luthans, 2002a, 2002b; Luthans \& Youssef, 2007; Luthans, Youssef, \& Avolio, 2007). While the domain of $\mathrm{POB}$ is still emerging, theoretical and empirical support continues to develop around positive constructs and state-like resource capacities. In addition, the emphases on performance impact and state-like psychological capacities have received attention in the current and future directions highlighted in organizational health psychology research (e.g., see Bakker, Schaufeli, Leiter, \& Taris, 2008; Xanthoupoulou, Baker, Heuven, Demerouti, \& Schaufeli, 2008).

In POB, Luthans and colleagues (Luthans, Luthans, \& Luthans, 2004, 2007; Luthans \& Youssef, 2004; Luthans, Youssef, \& Avolio, 2007) identified the positive constructs of efficacy, hope, optimism, and resilience as at least initially best meeting the inclusion criteria and in combination termed them "psychological capital." This psychological capital or simply PsyCap is defined as:

An individual's positive psychological state of development that is characterized by: (1) having confidence (self-efficacy) to take on and put in the necessary effort to succeed at challenging tasks; (2) making a positive attribution (optimism) about succeeding now and in the future; (3) persevering toward goals, and when necessary, redirecting paths to goals (hope) in order to succeed; and (4) when beset by problems and adversity, sustaining and bouncing back and even be- yond (resilience) to attain success. (Luthans, Youssef, \& Avolio, 2007, p. 3)

In this definition, PsyCap has the integrative, common thread running through the four dimensions (i.e., efficacy, optimism, hope, and resilience) of a motivational propensity to accomplish goals and succeed. Taken as a whole, PsyCap has been demonstrated conceptually (Luthans, Youssef, \& Avolio, 2007) and empirically (Luthans, Avolio, et al., 2007) to be a higher order core construct. Furthermore, it predicts desired employee outcomes such as performance and job satisfaction better than the individual resources independently (Luthans, Avolio, et al., 2007).

The positive psychological resources that comprise the core construct of PsyCap are fundamentally of a cognitive nature. For example, hope is defined as a "positive motivational state based on an interactively derived sense of successful (a) agency (goal directed agency) and (b) pathways (planning to meet goals)" (Snyder, Irving, \& Anderson, 1991, p. 287). Efficacy beliefs are defined as "one's conviction (or confidence) about his or her abilities to mobilize the motivation, cognitive resources or courses of action needed to successfully execute a specific task within a given context" (Stajkovic \& Luthans, 1998, p. 66) and is based on Bandura's Social Cognitive Theory $(1986,1997)$. Optimism is defined as the attributions one makes and the explanatory style one uses in response to events (Seligman, 1998). It is oriented toward evaluation of the past or recently occurring events - as opposed to only being oriented toward the future. Specifically, Seligman (1998) describes an optimist as a person who attributes the outcomes of positive events to internal, stable efforts, or causes, whereas negative events or outcomes are attributed to, or perhaps explained by specific, unstable, external events that perhaps were also unavoidable. Finally, resilience, the fourth component of PsyCap, is defined as one's ability to "bounce back" or rebound when faced with a disappointing outcome, setback or failure or even positive events (Luthans, 2002b). At the heart of resilience is the concept of adaptability - particularly when faced with adversity (Block \& Kremen, 1996; Masten et al., 1985). Such cognitive resources (e.g., efficacy, hope, optimism, and resiliency) fall within the boundaries of COR theory and are explicitly noted as having relevance and aligning with current trends in COR theory (Hobfoll, 2002). Thus, we propose that these four components combine into PsyCap to foster cognitive evaluations of the availability of resources as indicators in one's global assessment of wellness. 
In sum, we propose there is a linkage of PsyCap with the core aspect of psychological resource theory (i.e., the means of a cognitive appraisal of the situation). The theoretical mechanisms from psychological resources are characteristic of how PsyCap is defined, theorized and operationalized. Employees' PsyCap reinforces the potential value of their taking different perspectives, appraising situations and circumstances in more positive, opportunistic, adaptive and promotion/approach focused ways, thus enhancing their well-being. Thus, we hypothesize that:

H1: Employees' PsyCap is positively related to their PWB.

Given the importance of the role of time on organizational oriented relations, the limited longitudinal investigation of PWB and the potential role of common method variance artificially inflating relations among variables (e.g., see Podsakoff, MacKenzie, Lee, \& Podsakoff, 2003), it is important to understand the unique role of the proposed predictor PsyCap on PWB. Thus, we hypothesize that:

H2: When measured over time, employees' PsyCap will explain additional variance in their PWB at time two, controlling for their previous level of PWB at time one.

\section{Method}

\section{Sample and Procedure}

The study sample consisted of those who agreed to participate in a large Midwestern university sponsored research project on employees in today's workplace. They were asked to participate in a two-part, online survey lasting approximately 30 to $35 \mathrm{~min}$ for each session regarding employee attitudes and behaviors and organizational performance. Specifically, participants received an email from the researchers inviting them to participate in the study with directions to access a secure website where they reviewed the informed consent and the study's protocol. After agreeing to participate in the study, each participant logged in with their personal email address and was assigned a unique password to facilitate the matching of the participant responses from Time 1 to Time 2. Data were collected during these two time points three weeks apart. This time frame was cho- sen to allow for some variance in PWB (e.g., we did not anticipate change in one or two days) while still maintaining a captive audience to avoid a high level of attrition between data collection points.

After matching completed surveys from Time 1 to Time 2 and screening the data for incomplete entries and outliers, the study yielded 280 usable participant records out of 381 originally contacted yielding and overall response rate with no mortality of $73.4 \%$. These study participants were all working adults and had an average age of $31.7(S D=13.67)$. The sample was predominantly white $(86 \%)$, while 5\% were Asian, 3\% Hispanic, $3 \%$ Black, $1 \%$ Native American, and the remaining 2\% did not indicate their ethnic background. The sample was $51 \%$ male. For highest level of education completed, $70 \%$ indicated they had earned a high school diploma or equivalent; $16 \%$ held undergraduate degrees, $7 \%$ had earned a master's degree or higher, $1 \%$ did not finish high school, and the remaining $6 \%$ did not report their level of education. Participants represented a diverse range of industries, occupations, and job levels and had an average of 10.5 years of work experience $(S D=11.79)$.

\section{Measures}

PsyCap. PsyCap was measured using the PCQ-24 (the validity analysis can be found in Luthans, Avolio, et al., 2007, and Luthans, Youssef, \& Avolio, 2007, contains the entire PCQ-24 and free permission for research purposes can be obtained from www.mindgarden.com). PsyCap is a higher order construct, consisting of four subscales, each comprised of six items each for a total of 24 items. The subscales include hope, efficacy, resilience, and optimism. All items were measured using a 6-point Likert scale of agreement with response options ranging from $1=$ strongly disagree to $6=$ strongly agree. The scale items were drawn from established scales previously published and tested. They each have been used in other recent workplace studies (e.g., Luthans, Avolio, Walumbwa, \& Li, 2005; Youssef \& Luthans, 2007) and the PCQ-24 as a whole (Avey, Wernsing \& Luthans, 2008; Luthans, Avolio et al., 2007; Luthans et al., 2008).

The hope items were adapted from Snyder and colleagues (1996). Examples of items from the subscale of hope include: "There are lots of ways around any problem," and "Right now I see myself as being pretty successful at work." The efficacy items were adapted from Parker's (1998) measure of self-efficacy in the work situation. Examples of items from the subscale of efficacy include: "I feel confident analyzing a long-term prob- 
lem to find a solution," and "I feel confident presenting information to a group of colleagues." The resilience items were adapted from Wagnild and Young's (1993) measure. Examples of items from the subscale of resilience include: "I usually manage difficulties one way or another at work," and "I feel I can handle many things at a time at this job." The optimism items were adapted from Scheier and Carver's (1985) measure of optimism. Examples of items from the subscale of optimism include: "I'm optimistic about what will happen to me in the future as it pertains to work" and "I approach this job as if 'every cloud has a silver lining.'" Similar to the reliabilities found in the construct validation study of the PCQ-24 (Luthans, Avolio, et al., 2007), the reliability for the sample of this study was $\alpha=.93$ (hope $\alpha=.87$, efficacy $\alpha=.87$, resilience $\alpha=.72$, optimism $\alpha=.78$ ).

\section{PWB}

PWB in this study was measured by two widely recognized instruments, the Index of PWB and the General Health Questionnaire. The PWB measure is based on the scale used by Berkman (1971a, 1971b) in his research on emotional well-being and uses many of the same items as Bradburn and Caplovitz's (1965) measure of affect with a modification of the referent time frame. Validation evidence can be found in the Berkman (1971a) and in the Wright and Bonett (1992) studies. In past research, this measure has been operationalized as both mental health (Wright \& Bonett, 1992) and affective disposition (Wright \& Staw, 1999). Participants were asked to respond to eight items (three positively oriented and five negatively oriented) indicating the extent to which they feel a particular way "in general." For this study, the measure we obtained from Wright included a modified response scale which differs from previous scaling methods employed by Wright and colleagues in previous administrations of the measure (e.g., Berkman, 1971a; Wright, Bonett, \& Sweeney, 1993). This version of the scale utilized a 5-point, Likert-type scale including response options ranging from "very slightly or not at all" to "extremely." Reliability, as measured by Cronbach's alpha for the Index of PWB for this sample was Time 1, $a=$ .77 , and Time $2, \mathrm{a}=.75$.

The second well-being measure used in this study, the 12-item General Health Questionnaire (GHQ-12; Goldberg, 1972; Goldberg \& Hillier, 1979), is a commonly accepted measure of mental health/well-being that measures aspects of affect, general health and psy- chological distress (McKee-Ryan, Song, Wanberg, \& Kinicki, 2005). The GHQ-12 asks participants to rate 12 items regarding how their health has been "in general over the last few weeks." Response options are relative to how the participant "usually" feels and represent four options: "much less than usual, less than usual, same as usual, and better than usual." Items are representative of mental health symptoms and/or experiences (episodes). Sample items are to what extent have you "been able to concentrate on what you're doing?" and "lost much sleep over worry?" Reliability, as measured by Cronbach's alpha for the General Health Questionnaire (GHQ) for this sample was Time 1, $a=$ .79 and Time $2, \mathrm{a}=.80$.

Analyses and results. Descriptive statistics were computed for the variables in this study: age (in years), gender $(0,1)$, years of experience, job level (categories), education (codes), PsyCap Time1, GHQ Time 1 and 2, PWB Time 1 and 2. To test the first hypothesis assessing the relationship between PsyCap and the two measures of $\mathrm{PWB}$, bivariate correlations were calculated. The variable means, standard deviations and these bivariate correlations are shown in Table 1 . To test the second hypothesis, a series of hierarchical regressions were conducted in SPSS 15.0 to assess the incremental change in the amount of explained variance offered by PsyCap in PWB at Time 2, after controlling for PWB at Time 1. Analyses were conducted for both measures of PWB collected as part of this study. Standardized regression coefficients $\left(\beta^{\prime} \mathrm{s}\right)$, amount of explained variance $\left(R^{2}\right)$, and the amount of change in the explained variance $\left(\Delta R^{2}\right)$ between the variables are presented in Table 2.

Relationship of PsyCap to PWB. Consistent with expectations of reliable measures (i.e., test-retest reliability), both measures of PWB were highly correlated between their respective responses (i.e., within instruments) collected at Time 1 and Time 2 (PWB: $r=.75, p<.01$; GHQ: $r=.59, p<.01)$. In addition, the two measures of well-being were correlated with each other (i.e., between instruments) at Time 1 and at Time $2(r=.38, p<.01 ; r=.44, p$ $<.01)$. The relationships are positive, which is expected, but they are not so large to suggest they are nonindependent operationalizations of PWB.

As hypothesized and in support of Hypothesis 1 and 2, PsyCap was significantly correlated with both measures of PWB at both Time 1 and Time 2, although the relationship was stronger and more stable for the Index of PWB $(r=.47, p<.01)$, than for the GHQ at Time 1 and 2, respectively $(r=.24, p<.01 ; r=.27, p<.01)$. 
Table 1. Variable Means and Bivariate Correlations

\begin{tabular}{|c|c|c|c|c|c|c|c|c|c|c|c|c|}
\hline Variable & Mean & $S D$ & 1 & 2 & 3 & 4 & 5 & 6 & 7 & 8 & 9 & 10 \\
\hline 1. Age & 31.69 & 13.67 & & & & & & & & & & \\
\hline 2. Gender (DC) & & & -.17 & & & & & & & & & \\
\hline 3. Years experience & 10.51 & 11.79 & .89 & -.02 & & & & & & & & \\
\hline 4. Years service & 6.72 & 8.30 & .71 & -.02 & .75 & & & & & & & \\
\hline 5. Job level ${ }^{\mathrm{a}}$ & 1.69 & 1.20 & .40 & .11 & .35 & .36 & & & & & & \\
\hline 8. GHQ Time 1 & 2.69 & .38 & .00 & -.15 & -.01 & -.05 & .04 & .06 & .24 & & & \\
\hline 9. PWB Time 1 & 3.88 & .59 & .06 & -.15 & .06 & .00 & .05 & .06 & .47 & .38 & & \\
\hline 10. GHQ Time 2 & 2.69 & .36 & -.03 & -.09 & -.03 & -.04 & .02 & -.01 & .27 & .59 & .35 & \\
\hline 11. PWB Time 2 & 3.88 & .55 & .03 & -.11 & .04 & -.01 & .07 & -.04 & .47 & .29 & .75 & .44 \\
\hline
\end{tabular}

PsyCap = psychological capital; PWB = psychological well-being; GHQ = General Health Questionnaire; DC = dummy coded . Correlations greater than .10, $p<.05$; greater than .13, $p<.01$.

a Job level and Education are categorical variables, and their means and SDs should not be interpreted.

Finding support for Hypothesis 1 enables further examination of Hypothesis 2, which examines the relationship between PsyCap at Time 1 and PWB at Time 2, controlling for the effect of PWB at Time 1. Results of the hierarchical regression analyses are presented in Table 2. For clarity, the two-step process is presented side by side for each of the two respective measures of well-being. Furthermore, given the high correlation between years experience, tenure and age, we selected years of experience as the most relevant covariate from this group.
In this study, age, gender, years of experience, tenure, job level, and education were used as covariates. These demographic variables were included because Wright and colleagues (2007) have noted these status variables may be related to PWB. Thus, they were added in order to isolate the effect of PsyCap on well-being. In Step 1 for each measure of $\mathrm{PWB}$, we entered the demographic variables of age, gender, years of experience, tenure, job level and education into the model, along with the respective measure of PWB (PWB or GHQ). The squared multiple correlations for Index of PWB was .56 $(p<.05)$ and for

Table 2. Regression Analyses ( $\beta$ ) of the Effect of Psychological Capital (PsyCap) on Two Measures of Psychological Well-Being (PWB)

\begin{tabular}{|c|c|c|c|c|}
\hline \multirow[b]{2}{*}{ Variable } & \multicolumn{2}{|c|}{ Index of PWB at Time 2} & \multicolumn{2}{|c|}{$\begin{array}{l}\text { General Health Questionnaire } \\
\text { (GHQ) at Time } 2\end{array}$} \\
\hline & Step 1 & Step 2 & Step 1 & Step 2 \\
\hline \multicolumn{5}{|l|}{ PWB at Time 2} \\
\hline Gender & -.02 & -.01 & -.05 & -.04 \\
\hline Years experience & .01 & .04 & -.06 & -.04 \\
\hline Education & -.10 & -.13 & -.01 & -.03 \\
\hline GHQ Time 1 & & & $.57^{* *}$ & $.55^{* *}$ \\
\hline PWB Time 1 & $.75^{* *}$ & $.67^{* *}$ & & \\
\hline PsyCap Time 1 & & $.19^{* *}$ & & $.12^{*}$ \\
\hline Total $R^{2}$ & .56 & .59 & .32 & .34 \\
\hline$\Delta R^{2}$ & & $.03^{* *}$ & & $.02^{*}$ \\
\hline
\end{tabular}


the GHQ was $.32(p<.05)$. In Step 2, PsyCap at Time 1 was entered into the model, and in each analysis, the measure of PWB at Time 1 (PWB or GHQ) was entered as a control variable to assess the impact of PsyCap on PWB (PWB or GHQ) at Time 2, controlling for the level of PWB (PWB or GHQ) at Time 2. Of particular interest to this study, the squared multiple correlations for both measures of PWB increased with the addition of PsyCap and the control of Time 1 . The changes for both models were both significant (PWB increased from .56 to $.59, \Delta R^{2}$ $=.03, p<.01$; GHQ increased from .32 to $.34\left(\Delta R^{2}=.02, p\right.$ $<.05)$ supporting Hypotheses 1 and 2.

This analysis suggests that PsyCap at Time 1 offers a small, yet statistically significant, increment in explained variance for the criterion of PWB at Time 2, even after controlling for PWB at Time 1. In addition, the effect is present for both measures of well-being with differential influence. The impact of PsyCap on PWB explains an additional 3\% $(p<.01)$ of the variance as measured by the PWB and explains an additional $2 \%(p<.05)$ of the variance as measured by the GHQ.

\section{Discussion}

Although positive psychology has established the relationship between positivity and health outcomes (e.g., see Bandura, 2008; Lyubomirsky et al., 2005) and Wright and colleagues have established the relationship between PWB and performance in the workplace (Cropanzano \& Wright, 1999; Wright, Bonett, \& Sweeney, 1993; Wright \& Cropanzano, 2000; Wright \& Staw, 1999), the theoretical mechanisms relating positive, cognitively based psychological resources represented in this study by the core construct of PsyCap (made up of efficacy, hope, optimism, and resilience) with well-being and the role of time have not been explored.

This study drew from conservation of resources theory (COR; Hobfoll, 1989, 2002) and the recently emerging cognitively based core construct of PsyCap to meet this need for a better understanding of the positive antecedents to employee well-being. The results not only indicated that PsyCap, as representative of positive, work-related psychological resources, is related to two measures of well-being, but also added small, but significant, variance over time. Thus, this study provides preliminary evidence that positive resources such as employees' PsyCap may lead to the desirable outcome of their PWB over time.

A nuance in the data not anticipated was that there was not a strong relationship between Wright's index of PWB (modified from Berkman) and the general health questionnaire (GHQ) proxy for PWB. After reviewing the origins of the instruments, it was determined that Berkman's original work was in the area of emotional wellbeing and explicitly focused on affective actions and reactions. In contrast, the GHQ is focused more on mental health or an overtly cognitive component. While cognitions and emotions are intertwined, given PWB has both emotive and cognitive properties; it is likely that the PWB index tended toward more emotionally loaded items while the GHQ was more cognitive. However, given this is a post hoc explanation, more research on these two instruments is needed to understand their relationship and perhaps which is most optimal under what conditions. It should be noted, however, that given the relationships in this study, the PWB index did emerge as more related to the predictor overall.

While this research has several practical implications for addressing PsyCap and well-being, limitations and future research also need to be noted. First as with any empirical study that does not use a true experiment research design, it is not possible to say from this study that PsyCap causes PWB. While in this case the evidence does suggest a meaningful relationship over time and that PsyCap accounts for unique variance in PWB, causality still cannot be concluded. Another limitation of this study is that there is the potential for common method variance to artificially inflate the relationships between variables. While a temporal separation of measurement was used to help minimize the potential effect of common method variance (Podsakoff et al., 2003), this method does not eliminate the potential for inflated relationships between PsyCap and PWB. Given that both PsyCap and PWB are subjective in nature, they are arguably best evaluated by the self-referent. Thus, rather than attempting multisource ratings, a practical extension for future research may be longitudinal research designs over several time points, where latent growth curve modeling can better assess the nature of the relationship over time (see Avey, Luthans, \& Mhatre, 2008).

As to additional future research, the psychological resource theories generally consider personal and social dimensions as part of a complete assessment of the presence or absence of individual resources. In this study, we focused on individual-level psychological resources in the form of PsyCap. Though this initial assessment of the relationship of positive resources such as PsyCap is important for our understanding of the impact on well-being, future research needs to also incorporate social resources (e.g., social support, group membership, or having close friends) to fully test the contribution of group resources over and above individual resources. 
Another concern with this study is the explicit separation of PsyCap from $\mathrm{PWB}$, which has been identified as more trait-like (e.g., see Wright \& Hobfoll, 2004). The linkage of PsyCap with PWB implies that the process of adaptation associated with PsyCap may be separate from the process of adaptation associated with PWB. While we recognize human adaptation as a single individual process, it is a process that occurs over time. Thus, the adaptation associated with state-like resources can occur as a direct result of those resources (e.g., PsyCap) and as a function of more trait-like differences (e.g., PWB, which is influenced by psychological states). As occupational health researchers continue to posit differences in the temporal stability between PsyCap and PWB, it will be important for future research to evaluate how long the effects will last. For example, Wright (1997) suggests that a 6-month interval should be the minimum cut off between time periods when assessing constructs for state versus trait properties.

\section{Implications and Conclusion}

In the review of resource theories, Hobfoll (2002, p. 310) noted that it will be "important to determine the extent to which key resources can be enhanced by intervention, and, thus, whether what has been learned about the importance of key resources can be translated to fostering resilience." The presence of a relationship between statelike, developable PsyCap and PWB provides an example of one means by which malleable capacities could be used to examine the differential effects of interventions that seek to foster employee well-being in the workplace. Recently, Wright and colleagues (Wright et al., 2007, p. 101) noted that their research findings indicated that "individuals have the opportunity to learn ways to enhance their PWB through any number of training-based interventions." In complementary research, Luthans and colleagues demonstrated that PsyCap can be developed in short training interventions, which may include technology mediated delivery (Luthans, Avey, \& Patera, 2008; also see Luthans, Avey, Avolio, Norman, \& Combs, 2006, and Luthans, Youssef, \& Avolio, 2007, Chapter 8). Such interventions have included a focus on how to enhance each of the four dimensions of PsyCap drawing from work in positive psychology in each area. For a full discussion of how this training intervention is operationalized, see Luthans et al. (2006) and Luthans, Avey, and Patera (2008). Thus, as an investment in human capital, organizations can consider developmental experiences based on the PsyCap model in order to potentially enhance PWB of employees. This minimal cost of investing in PsyCap may be particularly useful, given the turbulent times most organizations (and employees) are currently experiencing.

In conclusion, this article provides preliminary evidence that PsyCap may be a positive resource used to enhance employee PWB. While well-being has been shown to have reciprocal effects on work-related outcomes such as job satisfaction, the means for understanding and affecting these reciprocal processes have received little attention. To that end, rationale from positive psychology, conservation of resources and psychological resource theories, in general, provide a theoretical grounding to better understand the mechanisms by which these reciprocal interactions may be fostered. The relationship found in this study between PsyCap and well-being over time provides an important potential construct in which to influence well-being and better understand its impact on more explicit occupational health outcomes. Additional research is now needed to understand other predictors of PWB and which, including PsyCap, may be the most appropriate technique for enhancing employees' PWB to meet specific personal and organizational challenges.

\section{References}

Avey, J. B., Luthans, F., \& Mhatre, K. H. (2008). A call for longitudinal research in positive organizational behavior. Journal of Organizational Behavior, 29, 705-711.

Avey, J. B., Wernsing, T. S., \& Luthans, F. (2008). Can positive employees help positive organizational change? The Journal of Applied Behavioral Science, 44, 48-70.

Axtell, C., Holman, D., Wall, T., Waterson, P., Harrington, E., \& Unsworth, K. (2000). Shopfloor innovation: Facilitating the suggestion and implementation of ideas. Journal of Occupational and Organizational Psychology, 73, 265-285.

Bakker, A. B., Schaufeli, W. B., Leiter, M. P., \& Taris, T. W. (2008). Work engagement: An emerging concept in occupational health psychology. Work and Stress, 22, 187-200.

Bandura, A. (1986). Social foundations of thought and action. Englewood Cliffs, NJ: Prentice Hall.

Bandura, A. (1997). Self-efficacy: The exercise of control. New York: Freeman.

Bandura, A. (2008). An agentic perspective on positive psychology. In S. J.Lopez (Ed.), Positive psychology: Exploring the best in people (Vol. 1, pp. 167-196). Westport, CT: Greenwood Publishing.

Baron, R. A. (1990). Environmentally induced positive affect: Its impact on self-efficacy, task performance, nego- 
tiation and conflict. Journal of Applied Social Psychology, 20, 368-384.

Berkman, P. L. (1971a). Life stress and psychological wellbeing: A replication of Langer's analysis in the midtown Manhattan study. Journal of Health and Social Behavior, 12, 35-45.

Berkman, P. L. (1971b). Measurements of mental health in a general population survey. American Journal of Epidemiology, 41, 105-111.

Block, J., \& Kremen, A. M. (1996). IQ and ego-resiliency: Conceptual and empirical connections and separateness. Journal of Personality and Social Psychology, 70, 349-361.

Bradburn, N. M., \& Caplovitz, D. (1965). Reports on happiness. Chicago: Aldine.

Britt, T. W., Adler, A. B., \& Bartone, P. T. (2001). Deriving benefits from stressful events: The role of engagement in meaningful work and hardiness. Journal of Occupational Health Psychology, 6, 53-63.

Brown, J. (1984). Effects of induced mood on causal attributions for success and failure. Motivation and Emotion, 8, 343-353.

Cameron, K. S., Dutton, J. E., \& Quinn, R. E. (Eds.). (2003). Positive organizational scholarship. San Francisco: Berrett-Koehler.

Carver, C. S., \& Scheier, M. F. (2001). Optimism, pessimism, and self-regulation. In E. C. Chang (Ed.), Optimism and pessimism: Implications for theory, research, and practice (pp. 31-51). Washington, DC: American Psychological Association.

Carver, C. S., Smith, R. G., Antoni, M. H., Petronis, V. M., Weiss, S., \& Derhagopian, R. P. (2005). Optimistic personality and psychosocial well-being during treatment predict psychosocial well-being among long-term survivors of breast cancer. Health Psychology, 24, 508-516.

Cozzarelli, C. (1993). Personality and self-efficacy as predictors of coping with abortion. Journal of Personality and Social Psychology, 65, 1224-1236.

Cropanzano, R., \& Wright, T. A. (1999). A 5-year study of change in the relationship between well-being and job performance. Consulting Psychology Journal, 51, 252-265.

Danner, D. D., Snowdon, D. A., \& Friesen, W. V. (2001). Positive emotions in early life and longevity: Findings from the nun study. Journal of Personality and Social Psychology, 80, 804-813.

Diener, E., \& Seligman, M. E. P. (2002). Very happy people. Psychological Science, 13, 81-84.

Ferris, P. A., Sinclair, C., \& Kline, T. J. (2005). It takes two to tango: Personal and organizational resilience as predictors of strain and cardiovascular disease risk in a work sample. Journal of Occupational Health Psychology, 10, 225-238.
Goldberg, D. P. (1972). The detection of psychiatric illness by questionnaire. London: Oxford University Press.

Goldberg, D. P., \& Hillier, V. F. (1979). A scaled version of the general health questionnaire. Psychological Medicine, $9,139-145$.

Graham, C., Eggers, A., \& Sukhtankar, S. (2004). Does happiness pay? An exploration based on panel data from Russia. Journal of Economic Behavior and Organization, 55, 319-342.

Heaphy, E. D., \& Dutton, J. E. (2008). Integrating organizations and physiology: Getting started. Academy of Management Review, 33, 1009-1010.

Hobfoll, S. E. (1989). Conservation of resources: A new attempt at conceptualizing stress. American Psychologist, $44,513-524$.

Hobfoll, S. E. (2002). Social and psychological resources and adaptation. Review of General Psychology, 6, 307-324.

Hom, H., \& Arbuckle, B. (1988). Mood induction effects upon goal setting and performance in young children. Motivation and Emotion, 12, 113-122.

Keyes, C. L. M. (2007). Promoting and protecting mental health as flourishing: A complementary strategy for improving national mental health. American Psychologist, 62, 95-108.

Koivumaa-Honkanen, H., Koskenvuo, M., Honkanen, R. J., Viinamaki, H., Heikkilae, K., \& Kaprio, J. (2004). Life dissatisfaction and subsequent work disability in an 11-year follow-up study. Psychological Medicine, 34, 221-228.

Levy, B. R., Slade, M. D., Kunkel, S. R., \& Kasl, S. V. (2002). Longevity increased by positive self-perceptions of aging. Journal of Personality and Social Psychology, 83, 261-270.

Luthans, F. (2002a). Positive organizational behavior: Developing and managing psychological strengths. Academy of Management Executive, 16, 57-72.

Luthans, F. (2002b). The need for and meaning of positive organizational behavior. Journal of Organizational Behavior, 23, 695-706.

Luthans, F., Avey, J. B., Avolio, B. J., Norman, S. M., \& Combs, G. M. (2006). Psychological capital development: Toward a micro-intervention. Journal of Organizational Behavior, 27, 387-393.

Luthans, F., Avey, J. B., \& Patera, J. L. (2008). Experimental analysis of a web-based training intervention to develop positive psychological capital. Academy of Management Learning and Education, 7, 209-221.

Luthans, F., \& Avolio, B. J. (2009). The "point" of positive organizational behavior. Journal of Organizational Behavior, 30, 291-307.

Luthans, F., Avolio, B. J., Avey, J. B., \& Norman, S. M. (2007). Positive psychological capital: Measurement and rela- 
tionship with performance and satisfaction. Personnel Psychology, 60, 541-572.

Luthans, F., Avolio, B. J., Walumbwa, F. O., \& Li, W. (2005). The psychological capital of Chinese workers: Exploring the relationship with performance. Management and Organization Review, 1, 249-271.

Luthans, F., Luthans, K. W., \& Luthans, B. C. (2004). Positive psychological capital: Beyond human and social capital. Business Horizons, 47(1), 45-50.

Luthans, F., Norman, S. M., Avolio, B. J., \& Avey, J. B. (2008). The mediating role of psychological capital in the supportive organizational climate-employee performance relationship. Journal of Organizational Behavior, 29, 2319-2238.

Luthans, F., \& Youssef, C. M. (2004). Human, social and now positive psychological capital management: Investing in people for competitive advantage. Organizational Dynamics, 33, 143-160.

Luthans, F., \& Youssef, C. M. (2007). Emerging positive organizational behavior. Journal of Management, 33, 321-349.

Luthans, F., Youssef, C. M., \& Avolio, B. J. (2007). Psychological Capital, Oxford, United Kingdom: Oxford University Press.

Lyubomirsky, S. (2008). The how of happiness. New York: Penguin Press.

Lyubomirsky, S., King, L., \& Diener, E. (2005). The benefits of frequent positive affect: Does happiness lead to success? Psychological Bulletin, 131, 803-855.

Maslow, A. H. (1954). Motivation and personality. New York: Harper.

Masten, A. S., Garmenzy, N., Tellegen, A., Pellegrini, D., Larken, K., \& Larsen, A. (1985). Competence and stress in school children: The moderating effects of individual and family qualities. Journal of Child Psychology and Psychiatry, 29, 745-764.

McKee-Ryan, F. M., Song, Z., Wanberg, C. R., \& Kinicki, A. J. (2005). Psychological and physical well-being during unemployment: A meta-analytic study. Journal of Applied Psychology, 90, 53-76.

Meier, L. L., Semmer, N. K., Elfering, A., \& Jacobshagen, N. (2008). The double meaning of control: Three-way interactions between internal resources, job control, and stressors at work. Journal of Occupational Health Psychology, 13, 244-258.

Mroczek, D. K., \& Spiro, A. (2005). Change in life satisfaction during adulthood: Findings from the veterans affairs normative aging study. Journal of Personality and Social Psychology, 88, 189-202.

Myers, D. G., \& Diener, E. (1995). Who is happy? Psychological Science, 6, 10-19.

O'Brien, L. T., \& Major, B. (2005). System-justifying beliefs and psychological well-being: The roles of group status and identity. Personality and Social Psychology Bulletin, 31, 1718-1729.

Ostir, G. V., Markides, K. S., Peek, M. K., \& Goodwin, J. S. (2001). The association between emotional well-being and the incidence of stroke in older adults. Psychosomatic Medicine, 63, 210-215.

Parker, S. (1998). Enhancing role-breadth self-efficacy: The roles of job enrichment and other organizational interventions. Journal of Applied Psychology, 83, 835-852.

Podsakoff, P. M., MacKenzie, S. B., Lee, J., \& Podsakoff, N. P. (2003). Common method bias in behavioral research: A critical review of the literature and recommended remedies. Journal of Applied Psychology, 88, 879-903.

Quick, J. C. (1999). Occupational Health Psychology: The convergence of health and clinical psychology with public health and preventive medicine in an organizational context. Professional Psychology: Research and Practice, 30, 123-128.

Quick, J. C., Quick, J. D., Nelson, D. L., \& Hurrell, J. J., Jr. (1997). Preventive stress management in organizations. Washington, DC: American Psychological Association.

Roysamb, E., Tawls, K., Reichborn-Kjenneruc, T., Neale, M. C., \& Harris, J. R. (2003). Happiness and health. Journal of Personality and Social Psychology, 85, 1136-1146.

Scheier, M. F., \& Carver, C. S. (1985). Optimism, coping, and health: Assessment and implications of generalized outcome expectancies. Health Psychology, 4, 219-247.

Schuettler, D., \& Kiviniemi, M. T. (2006). Does how I feel about it matter? The role of affect in cognitive and behavioral reactions to chronic illness diagnosis. Journal of Applied Social Psychology, 36, 2599-2618.

Seligman, M. E. P. (1998). Learned optimism. New York: Pocket Books.

Seligman, M. E. P., \& Csikszentmihalyi, M. (2000). Positive psychology. American Psychologist, 55, 5-15.

Seligman, M. E. P., Steen, T. A., Park, N., \& Peterson, C. (2005). Positive psychology progress: Empirical validation of interventions. American Psychologist, 60, 410-421.

Snyder, C. R., Irving, L. M., \& Anderson, J. R. (1991). Hope and health. In C. R. Snyder \& D. R. Forsyth (Eds.), Handbook of social and clinical psychology: The health perspective (pp. 285-305). Elmsford, NY: Pergamon Press.

Snyder, C. R., Lehman, K. A., Kluck, B., \& Monsson, Y. (2006). Hope for rehabilitation and vice versa. Rehabilitation Psychology, 51, 89-112.

Snyder, C. R., Sympson, S., Ybasco, F., Borders, T., Babyak, M., \& Higgins, R. (1996). Development and validation of the state hope scale. Journal of Personality and Social Psychology, 70, 321-335.

Stajkovic, A., \& Luthans, F. (1998). Social cognitive theory 
and self-efficacy: Going beyond traditional motivation and behavioral approaches. Organizational Dynamics, 26, 62-74.

Wagnild, G. M., \& Young, H. M. (1993). Development and psychometric evaluation of the resiliency scale. Journal of Nursing Management, 1, 165-178.

Westman, M., Hobfoll, S. E., Chen, S., Davidson, O. B., \& Laski, S. (2005). Organizational stress through the lens of Conservation of Resources (COR) theory. In P. L. Perrewe \& D. C. Ganster (Eds.), Research in occupational stress and well-being (Vol. 4, pp. 167-220). Amsterdam: JAI Press.

Williams, S., \& Cooper, C. L. (1998). Measuring occupational stress: Development of the pressure management indicator. Journal of Occupational Health Psychology, 3, 306-321.

Wright, T. A. (1997). Time revisited in organizational behavior. Journal of Organizational Behavior, 18, 201-204.

Wright, T. A. (2003). Positive organizational behavior: An idea whose time has truly come. Journal of Organizational Behavior, 24, 437-442.

Wright, T. A. (2005). The role of "happiness" in organizational research: Past, present and future directions. In P. L.Perrewe \& D. C. Ganster (Eds.), Research in occupational stress and well-being (pp. 221-264). Amsterdam: JAI Press.

Wright, T. A., \& Bonett, D. G. (1992). The effect of turnover on work satisfaction and mental health: Support for a situational perspective. Journal of Organizational Behavior, 13, 603-615.
Wright, T. A., \& Bonett, D. G. (2007). Job satisfaction and psychological well-being as nonadditive predictors of workplace turnover. Journal of Management, 33, 141-160.

Wright, T. A., Bonett, D. G., \& Sweeney, D. A. (1993). Mental health and work performance: Results of a longitudinal field study. Journal of Occupational and Organizational Psychology, 66, 277-284.

Wright, T. A., \& Cropanzano, R. (2000). Psychological well-being and job satisfaction as predictors of job performance. Journal of Occupational Health Psychology, 5, 84-94.

Wright, T. A., Cropanzano, R., \& Bonett, D. G. (2007). The moderating role of employee positive well being on the relation between job satisfaction and job performance. Journal of Occupational Health Psychology, 12, 93-104.

Wright, T. A., \& Hobfoll, S. E. (2004). Commitment, psychological well-being and job performance: An examination of conservation of resources (COR) theory and job burnout. Journal of Business and Management, 9, 389-406.

Wright, T. A., \& Staw, B. M. (1999). Affect and favorable work outcomes: Two longitudinal tests of the happyproductive worker thesis. Journal of Organizational Behavior, 20, 1-23.

Xanthoupoulou, D., Bakker, A. B., Heuven, E., Demerouti, E., \& Schaufeli, W. B. (2008). Working in the sky: A diary study on work engagement among flight attendants. Journal of Occupational Health Psychology, 13, 345-356.

Youssef, C., \& Luthans, F. (2007). Positive organizational behavior in the workplace: The impact of hope, optimism, and resilience. Journal of Management, 33, 774-800. 